\title{
AN EPIDEMIOLOGICAL STUDY TO ASSESS THE SOCIAL FACTORS DETERMINING THE CAUSE OF ABSENTEEISM IN CLASS IV EMPLOYEES RESIDING IN URBAN AREA OF SHIMOGA.
}

Syed Hubbe Ali

1. Assistant Professor. Department of Community Medicine, Subbaiah Medical College, Shimoga,

\section{CORRESPONDING AUTHOR:}

Dr. Syed Hubbe Ali,

Flat No. 302A, professors Quarters,

Subbaiah Medical College, Shimoga.

E-mail: drsyed_ali@rediffmail.com

ABSTRACT: CONTEXT: Absenteeism is a perennial problem in Industry. The organization should be concerned over the abnormal increase in absence rate, as it is an indicator of discipline in the organization as well as reflection in the supervisory effectiveness. AIMS: To depict the epidemiological and social factors responsible for Absenteeism in class IV employees. SETTINGS AND DESIGN: Urban area in Shimoga District of Karnataka, Cross sectional study. MATERIALS AND METHODS: The present study was a community based, cross sectional study carried out in an urban area (Tunga Nagar) in Shimoga District among class IV employees from November 2012- February 2013. Ethical clearance was obtained. During the survey a total 111 persons were found to be employed as class IV in Government and private sector. A predesigned and pre-tested questionnaire was used to collect information regarding the sociodemographic profile. . A detailed history regarding job status and work place was elicited. An enquiry was made to obtain the history of various causative factors resulting in absenteeism. A meticulous search was carried out to ascertain role of addictions, working conditions and working relationships with the absenteeism rate. RESULTS: The main social factor responsible for absenteeism in our study was medical leave due to sickness (36.9\%) followed by leave on the occasion of children's vacation (28.8\%) and festival occasion (18\%). 20.7\% of absenteeism in year 2011 -2012 in study subjects was more than the entitled leave, the causes of which were found to be alcoholism (60.9\%) and illness (39.1\%). Another reason for absenteeism could be Job dissatisfaction which was found to be 48.6\%.CONCLUSION: Absenteeism results in dislocation of work increase in labour cost, reduction in productivity and if unchecked increases indiscipline. Although some amount of absence is inevitable, most of it can be avoided and every organization should take necessary steps to minimize absenteeism.

KEY WORDS: Absenteeism, Class IV employees, alcoholism, job satisfaction

INTRODUCTION: Absenteeism is a perennial problem in Industry. An enterprise to keep going requires the assurance of a stable workforce (1).Information regarding absenteeism in workers on account of reasons other than strikes, lockouts, lay-off, weekly rest or suspension, provide a sound database for gauging the employees morale, commitment and level of job satisfaction which have a direct bearing on productivity. The effects of high levels of absenteeism are wide ranging and affect everyone in the organization. It cannot be regarded purely as management problem. (2) The organization should be concerned over the abnormal increase in absence rate, as it is an indicator of discipline in the organization as well as reflection in the supervisory effectiveness. Absenteeism is an industrial malady affecting production, productivity, profit and 
investments in the absentee workers themselves. Its consequences are alarming, as a day lost is a resource lost- deprived of being invested.(3) Adequate importance has not yet being given to the problem of absenteeism in India, perhaps due to existence of adequate manpower. The rate of absenteeism is lower in Western Europe than India, which could be assigned to the industrial consequences of workers. In India data on absenteeism are collected and compiled by two agencies viz. the Labor Bureau, Shimla and the Annual Survey of Industries. (4) Since there were not many studies on causes of absenteeism in class IV employees, the present study was undertaken in urban area of Shimoga District to depict the epidemiological and social factors responsible for absenteeism in class IV employees.

MATERIALS AND METHODS: The present study was a community based, cross sectional study carried out in an urban area (Tunga Nagar) in Shimoga District among class IV employees from November 2012- February 2013. Ethical clearance was obtained. Tunga Nagar is the Urban field practice area of Dept. of Community Medicine, Subbaiah Medical College Shimoga, situated $5 \mathrm{Kms}$ from the College. Tunga Nagar has a population of 13,000. It shelters about 2,300 families, i.e. 13,000 people. All 2130 houses were surveyed using complete enumeration technique. House to house approach was used for the initial enumeration. During the survey a total 111 persons were found to be employed as class IV in Government and private sector. Those working as maid in houses were excluded from the study.

The study is based on the "Concept of Absenteeism" (5) -

According to English Oxford dictionary, "Absenteeism is practice of being absentee or absenting oneself from duty or station"....

J.C. Hacket defines "Absenteeism" as temporary cessation of work for not less than whole working day on the initiative of the worker when his presence is expected by the employer....

Alfred defines.... "as time lost from other than leave of management. Absenteeism is available time lost to production"....

All 111 employees were interviewed. Information regarding socio- demographic profile was questioned. Personal particulars were noted. A detailed history regarding job status and work place was elicited. An enquiry was made to obtain the history of various causative factors resulting in absenteeism. A meticulous search was carried out to ascertain role of addictions, working conditions and working relationships with the absenteeism rate. The findings were subsequently tabulated, analyzed and inference was drawn.

RESULTS: Total number of leave Entitled Vs. leave Availed in previous academic year i.e. from April 2011 to March 2012 was enquired.

\begin{tabular}{|l|l|l|}
\hline Entitlement & No. of Employees & Percentage \\
\hline Less than entitlement & 17 & 15.3 \\
\hline As per entitlement & 71 & 63.9 \\
\hline More than entitlement & 23 & 20.7 \\
\hline Total & 111 & 100 \\
\hline
\end{tabular}

Table 1: Entitled leave availed distribution in previous year

Out of these employees, 23 have availed Leave without pay (L.W.P.). The cause of Absenteeism in these employees is indicated as under: 


\begin{tabular}{|l|l|l|}
\hline Cause & No. of Employees & Percentage \\
\hline Medical & 9 & 39.1 \\
\hline Alcoholism & 14 & 60.9 \\
\hline Total & 23 & 100 \\
\hline
\end{tabular}

Table 2: Cause of LWP

DISCUSSION: The present study was undertaken in urban area of Shimoga District to depict the epidemiological and social factors responsible for absenteeism in class IV employees. Absenteeism is defined by M.J.Jucins as any failure of an employee to report for or to remain at work as scheduled, regardless of reason, the term "as scheduled" is very important as this automatically excludes vacations, holidays, jury duty and the like.(6) In our study out of total class IV employees i.e. 111(89 male, 22 female) maximum 40.5\% were working as peon, 19.8\% as attendant, $17.1 \%$ as cook, $15.4 \%$ as sweeper, $4.5 \%$ as helper/electrician and $2.7 \%$ as liftman. The worker is to be considered on schedule to work, when the employer has work for him/her and the worker is aware of it.(7) The main social factor responsible for absenteeism in our study was medical leave due to sickness (36.9\%) followed by leave on the occasion of children's vacation (28.8\%) and festival occasion (18\%). In a study conducted by Desai K.G. "Absenteeism in Industries" the main causes of Absenteeism are as follows (8)--

1) Selfish motives and personal rights valued more important than group interest and team work.

2) Improper selection and recruitment criteria

3) Health benefit abuses

4) Employee's personal habits

5) Dissatisfaction with job- no challenge or responsibility

6) Medical causes- psychiatric and physical illness.

The time period preferred for Leave, in our study was April to June (53.1\%) followed by October to December (33.3\%). This coincides with leave during children's vacation and during festival (Diwali, Christmas etc.) respectively. 20.7\% of absenteeism in year 2011 -2012 was more than the entitled leave, the causes of which were found to be alcoholism $(60.9 \%)$ and illness (39.1\%). On further analysis of alcohol consumption among study subjects, $39.6 \%$ were found to be addicted to alcohol with frequent consumption. An expert sub- committee of World health Organization (WHO) has defined Alcoholics as-"Alcoholics are those excessive drinkers whose dependence on alcohol has attained such a degree that it shows a noticeable mental disturbance or an interference with their bodily and mental health, their personal relations and their smooth social and economic functioning, and who show the prodromal signs of such development". (9) Another reason for absenteeism could be Job dissatisfaction which was found to be $48.6 \%$.

Other research studies in India and abroad have enumerated following factors associated with increase in absenteeism (10)-

A) Personal:

- Age: Proven research shows that older employees tend to be absent less frequently than younger ones (as time stabilizes them in their jobs and the thrill of an unauthorized day off no longer tempts them.) However, once an older employee is actually absent - usually for sickness leaves - the period of absenteeism is usually longer than that of a younger employee. 
- Gender: Women tend to be absent more frequently than men usually, especially when they are responsible for the welfare of a family and have variables beyond their control to contend with.

- Seniority: If an employee has been with a company for a long time, his/her absence level tends to become relatively lower. Fresh employees by contrast, are usually tempted to benefit from an "unauthorized" day off to relax and unwind.

- Personal Attitude: Employees with solid work ethics value the contribution they make to their companies and rarely allow themselves to take unauthorized time off. On the other hand people with a poor work ethic don't frequently carry the same amount of responsibility and do not feel obliged to show up to work every single day.

B) Workplace:

- Job Stress: When a job is stressful, employees tend to take unauthorized casual days off in order to reduce their stress levels and get rid of tension.

- Daily Job Routine: People with repetitive and monotonous jobs tend to take advantage of a casual absence to break free from their somewhat boring daily routine and engage in something more interesting for the day.

- Job Satisfaction: This is interrelated to daily job routine. The more an employee is dissatisfied with his overall job functions, the more he absentees himself from work.

CONCLUSION: Absenteeism results in dislocation of work, increase in labour cost, reduction in productivity and if unchecked increases indiscipline. Although some amount of absence is inevitable, most of it can be avoided and every organization should take necessary steps to minimize absenteeism.

Dealing with Absenteeism at workplace:

1) Design a comprehensive leave policy that is in alignment with company's values and objectives

2) The workplace communication while dealing with sensitive issue like absenteeism should be clear and transparent. Employees should be made aware of the adverse effects of unauthorized time off.

3) Monitor the attendance of all employees.

4) Acknowledge regularity and punctuality and reward appropriately.

5) Try to know the reason behind an employee's leave of absence. Face to face conversation might help.

6) Conduct regular health check- ups to curb absenteeism due to illness.

7) Introduce Employee engagement programs to involve the employees to participate actively in the welfare of the organization.

8) Supervisors should be trained to understand the psyche behind absenteeism, and eventually decrease it.

9) Introducing counseling could prove beneficial.

10) Keep your staff motivated by creating a favorable environment.

Absenteeism in the work place can be controlled if adequate measures are taken. To attain zero absenteeism is next to impossible. But with the control in place decrease in absenteeism is guaranteed. (11) 


\section{REFERENCES:}

1. Armstrong Michael - Handbook of Personnel management Practice (1 ${ }^{\text {st }}$ Edition 1996, Pg. 324)

2. Annual Survey of Industries - Govt. of India 2002-03, Vol.II, Report on absenteeism, Labour turnover, Labour cost. Chapter 2. Pg. 1

3. Beach D. S. - Personnel- The Management of people at Work (5 ${ }^{\text {th }}$ Edition 2011).Pg No.441

4. Bhatia S K - Management of absenteeism - based on case studies in Indian Industry ( Chapter 2,Asian Publication services, New Delhi 1981)

5. Ewing David. W.- "The Knowledge of an Executive" in Educational development services (1 $1^{\text {st }}$ Revision 2008), Pg.168.

6. Absenteeism and Industrial Development: Causes, Impact and Control measures Kavita Tiwari 1995, Pg,240.

7. David A. Decanzo and Stephen P. Robins- Personnel and human resource management. (7th Edition 2012) Pg.1141.

8. Desai K.G. "Absenteeism in Industries" Indian Journal of Social Work, 1966 Pg 27.

9. World Health Organization, TRS No.48. Pg. No. 16

10. Absenteeism in Work Place-Bayt International, career article No. 2821. Pg. 2-3.

11. Lalan Malaikal - "Absenteeism in the work place" 2011. $1^{\text {st }}$ Edition.Workplace Ethics and Dealing with Absenteeism. Pg. 57. 